Buyung Adinda Lokananta \& Anak Agung Sagung Alit Widyastuty : Pengembangan Ujung Jembatan Suramadu Berdasarkan Persepsi Pedagang (Studi Kasus Desa Sukolilo Kecamatan Labang Bangkalan Madura)

\title{
PENGEMBANGAN UJUNG JEMBATAN SURAMADU BERDASARKAN PERSEPSI PEDAGANG \\ (studi kasus Desa Sukolilo Kecamatan Labang Bangkalan Madura)
}

\author{
Buyung Adinda Lokananta ${ }^{\star *}$ ) dan Anak Agung Sagung Alit Widyastuty *)
}

\begin{abstract}
Abstrak
Pulau Madura tidak hanya dikenal dengan keanekaragaman budaya yang dimilikinya. Saat ini Pulau Madura lebih dikenal karena adanya Jembatan Suramadu. Jembatan Suramadu adalah jembatan yang menghubungkana antara Pulau Jawa dan Pulau Madura, sisi Pulau Jawa berada dikota Surabaya kawasan Kenjeran, sedangkan sisi Pulau Madura berada didesa Sukolilo Kecamatan Labang Bangkalan Madura. Sejak diresmikannya jembatan Suramadu Tahun 2009 hingga sekarang tidak diimbangi dengan pembangunan infrastruktur jalan maupun sarana prasarana yang baik. Hal ini dikarenakan belum adanya konsep pengembangan untuk kawasan ujung jembatan Suramadu bagian sisi Madura, sehingga perlu adanya penelitian tentang konsep pengembangan kawasan ujung Suramadu sisi Madura berdasarkan persepsi Pedagang yang bertujuan untuk meningkatkan perekonomian pedagang yang berada di area ujung jembatan Suramadu. Metode penelitian yang digunakan adalah metode analisis deskriptif kualitatif dengan pengumpulan data melalui wawancara, observasi dan penyebaran kuisoner pada kawasan yang akan dijadikan konsep pengembangan. Populasi penelitian adalah seluruh pedagang yang berada di area ujung jembatan Suramadu, sedangkan jumlah sampel sebanyak 57 responden yang didapat dari sebagian keseluruhan jumlah pedagang desa Sukolilo. Dari hasil analisis deskriptif kualitatif dianalaisis dengan metode SWOT sehingga menghasilkan rumusan strategi pengembangan ujung Suramadu berdasarkan persepsi Pedagang. Strategi stability adalah hasil dari analisis yang telah didapatkan dari perumusan SWOT yang dimana perlu adanya bantuan pemerintah baik dari segi peningkatan mutu pendidikan dan bantuan modal serta penyuluhan atau arahan yang bertujuan untuk menjadikan penduduk sekitar lebih maju dan dapat mengembangkan kawasan menjadi lebih nyaman sehingga dapat dipergunakan untuk mata pencaharian yang baru. Tidak hanya tertuju pada penduduk sekitar saja namun dengan adanya kerjasama antara pemerintah dengan pihak swasta juga berperan penting untuk membuat kawasan ini lebih banyak dikenal, misal dengan promosi kawasan dengan berbagai potensi yang bisa menjadi daya tarik wisatawan.
\end{abstract}

Kata Kunci : Pengembangan, Persepsi Pedagang, Ujung jembatan Suramadu.

\section{PENDAHULUAN}

Madura adalah nama Pulau yang terletak disebelah Timur laut Jawa Timur yang mempunyai luas kurang lebih $5.168 \mathrm{~km}^{2}$. Pulau Madura didiami oleh suku Madura yang merupakan etnis suku dengan populasi terbesar di Indonesia. Pekerja keras dan gaya bicara yang blak-blakan adalah ciri yang dimiliki masyarakat Madura. Pulau Madura mempunyai empat Kabupaten yakni Kabupaten Bangkalan, Sampang, Pamekasan dan Sumenep dan memiliki total 68 Kecamatan. Saat ini salah satu wilayah yang berada di Kabupaten Bangkalan lebih banyak dikenal oleh kalangan luas karena menjadi gerbang jembatan Suramadu. Jembatan Suramadu adalah jembatan yang menghubungkan antara Pulau Jawa (di Surabaya) dengan Pulau Madura (di Bangkalan). Dengan panjang $5.438 \mathrm{~m}$, jembatan ini merupakan jembatan terpanjang di Indonesia.

Pembangunan jembatan Suramadu ditujukan untuk mempercepat pembangunan di Pulau Madura, meliputi bidang infrastruktur dan ekonomi di Madura yang relatif tertinggal dibandingkan wilayah lain di Jawa Timur. Jembatan Suramadu terletak di Kecamatan Labang Bangkalan lebih tepatnya yang menjadi ujung Jembatan Suramadu adalah Desa Sukolilo. Data menunjukkan bahwa penduduk Desa Sukolilo adalah penduduk yang masih tertinggal ini dikarenakan tidak adanya infrastruktur yang memadai guna menghubungkan dengan wilayah lain.

\footnotetext{
**) Mahasiswa PWK

*) Dosen PWK

Universitas PGRI Adi Surabaya
} 
Buyung Adinda Lokananta \& Anak Agung Sagung Alit Widyastuty : Pengembangan Ujung Jembatan Suramadu Berdasarkan Persepsi Pedagang (Studi Kasus Desa Sukolilo Kecamatan Labang Bangkalan Madura)

Taraf kehidupan mereka juga dibawah ratarata dimana sebagian besar penduduk bekerja sebagai petani dan nelayan. Hanya pekerjaan bertani dan bernelayan yang bisa mereka kerjakan karena sebagian besar penduduk Desa Sukolilo tingkat pendidikannya sangat rendah, mereka hanya mengenyam pendidikan sampai SD atau SMP. Dengan pendidikan rendah mereka tidak mampu untuk mencari pekerjaan lain untuk mencukupi kebutuhan sehari-harinya.

Namun dengan adanya
pembangunan jembatan Suramadu memberikan dampak positif untuk penduduk Desa Sukolilo dan sekitarnya karena dengan begitu mereka bisa memanfaatkan kesempatan ini untuk mendapatkan pemasukan tambahan guna mencukupi kebutuhan sehari-hari mereka. Dengan kesempatan yang ada maka mata pencaharian mereka saat ini tidak hanya dari bertani dan bernelayan tetapi mereka mendapatkan tambahan dari membuka lapak dagang diarea ujung Suramadu. Awal peresmian jembatan Suramadu menjadikan antusias yang menarik bagi penduduk sekitar untuk menggelar dagangnnya, data menunjukkan jumlah pedagang hampir mencapai 600 pedagang. Namun di Tahun keempat peresmian jembatan Suramadu jumlah pedagang menurun cukup tajam, jumlahnya

Kurangnya minat wisatawan serta menurunnya jumlah pedagang area ujung Suramadu sisi Madura ini dikarenakan tidak adanya penataan khusus yang dilakukan oleh pemerintah pada area ujung Suramadu. Pada area ujung Suramadu sisi Madura telah diberi area khusus, pada area ini terdapat sarana prasrana dengan fasilitas MCK, Musholla, tempat peristirahatan, Lahan dan lapak pedagang bantuan pemerintah serta sarana informasi wisata. Namun sayangnya fasilitas ini tidak diimbangi dengan perawatan serta pantauan khusus dari pemerintah sehingga area yang tadinya bisa digunakan untuk memberikan kenyamanan bagi para wisatawan dan pelanggan saat ini terlihat tidak banyak berfungsi selayaknya. Dengan kondisi yang saat ini ada maka perlu adanya sebuah konsep pengembangan ujung Suramadu yang bertujuan untuk meberikan kenyamanan bagi para pengunjung serta memberikan kesempatan pada penduduk sekitar untuk mendapatkan penghasilan tambahan dengan tetap menjaga dan melestarikan apa yang sudah ditentukan oleh pemerintah.

Tujuan dari penelitian ini adalah mendapatkan konsep pengembangan ujung jembatan Suramadu berdasarkan persepsi pedagang melalui identifikasi sarana dan prasarana, potensi seni budaya dan pemanfaatan lahan dan lapak pedagang. Manfaat dari penelitian ini adalah memberikan kontribusi kepada pemerintah dalam penyusunan perencanaan tata ruang di ujung jembatan Suramadu berdasarkan dari pandangan para pedagang yang berada di area ujung jembatan Suramadu.

Konsep pengembangan wilayah di Indonesia lahir dari suatu proses interatif yang menggabungkan dasar-dasar pemahaman teoritis dengan pengalamanpengalaman praktis sebagai bentuk penerapannya yang bersifat dinamis. Dengan kata lain, konsep pengembangan wilayah di Indonesia merupakan penggabungan dari berbagai teori dan model yang senantiasa berkembang yang telah diujiterapkan dan kemudian dirumuskan kembali menjadi suatu pendekatan yang disesuaikan dengan kondisi dan kebutuhan pembangunan di Indonesia.

Dalam sebuah pengembangan wilayah akan banyak mengalami dampak perubahan yang signifikan diantaranya : berubahnya orientasi pembangunan yang harus bertumpu pada peningkatan individu, kelompok dan pemberdayaan masyarakat dalam menghadapi persaingan global, sehingga memungkinkan masyarakat mampu bertahan (survive), mengembangkan diri dan meningkatkan kesejahteraan, Semakin pentingnya peran lembaga non pemerintah seperti, pihak swasta, masyarakat, dan lembaga swadaya masyarakat (LSM) dalam pelaksanaan pembangunan dan pembiayaan, Terjadinya peningkatan urbanisasi di pinggiran kota besar dibandingkan di dalam kota besar itu sendiri. Hal ini sejalan dengan konsep yang dikembangkan oleh Mc. Gee pada tahun 1980-an. Batas antara kawasan perkotaan dan pedesaan semakin tidak jelas akibat pertumbuhan ekonomi, Dimana kegiatan perkotaan telah berbaur dengan perdesaaan dengan intensitas pergerakan investasi, ekonomi dan penduduk semakin tinggi.

Secara umum sarana dan prasarana adalah alat penunjang keberhasilan suatu proses yang dilakukan di dalam pelayanan publik, karena apabila kedua hal ini tidak tersedia maka semua kegiatan yang 
Buyung Adinda Lokananta \& Anak Agung Sagung Alit Widyastuty : Pengembangan Ujung Jembatan Suramadu Berdasarkan Persepsi Pedagang (Studi Kasus Desa Sukolilo Kecamatan Labang Bangkalan Madura)

dilakukan tidak akan mencapai hasil yang diharapkan sesuai dengan rencana. Moenir (1992 ; 119) mengemukakan bahwa sarana adalah segala jenis peralatan, perlengkapan kerja dan fasilitas yang berfungsi sebagai alat utama atau pembantu dalam pelaksanaan pekerjaan, dan juga dalam rangka kepentingan yang sedang berhubungan dengan organisasi kerja. Berdasarkan pengertian diatas, maka sarana dan prasarana pada dasarnya memiliki fungsi utama sebagai berikut : Mempercepat proses pelaksanaan pekerjaan sehingga dapar menghemat waktu, Meningkatkan produktivitas, baik barang maupun jasa, Hasil kerja lebih berkualitas dan terjamin, Lebih memudahkan atau sederhana dalam gerak para pengguna/pelaku, Ketepatan susunan stabilitas pekerja lebih terjamin, Menimbulkan rasa kenyamanan bagi orangorang yang berkepentingan, Menimbulkan rasa puas pada orang-orang yang berkepentingan yang mempergunakannya.

Budaya adalah bentuk jamak dan kata Budi dan Daya yang berarti cinta karsa dan karsa. Kata budaya sebenamya berasal dan bahasa sansekerta budha yha yaitu bentuk jamak kata buddhi yang berarti budi atau akal. Dalam bahasa inggris kata budaya berasal dan kata culture, dalam bahasa Belanda diistilahkan dengan kata cultur, dalam bahasa latin berasal dan kata colera. Colera berarti mengolah, mengerjakan, menyuburkan, mengembangkan tanah (bertani).
Kemudian pengertian ini berkembang dalam arti culture yaitu sebagai segala daya dan aktifitas manusia untuk mengolah dan mengubah alam berikut pengertian budaya atau kebudayaan dan beberapa ahli: E. B. Tylor, budaya adalah suatu keseluruhan komplek yang meliputi pengetahuan, kepercayaan, moral, keilmuwan, hukum, adat istiadat, dan kemampuan yang lain serta kebiasaan yang didapat oleh manusia sebagai anggota masyarakat, R. Linton, kebudayaan dapat dipandang sebagai konfigurasi tingkah laku yang dipelajari dan hasil tingkah laku yang dipelajari.

\section{METODE PENELITIAN}

Metode yang digunakan dalam studi konsep pengembangan ujung Suramadu adalah metode penelitian deskriptif kualitatif dan melakukan pengamatan secara langsung, penyebaran kuisioner, wawancara dengan menggunakan jumlah sampel 57 Responden yang didapat dari sebagian populasi pedagang, serta dokumen yang didapat dari terbitan maupun sumber dari instansi terkait. Dari analisis yang didapat pada kawasan kemudian dirumuskan pada metode SWOT yang akan menghasilkan sebuah strategi guna menjadikan kawasan lebih berkembang dan dapat memberikan keamanan bagi penggunanya. Berikut adalah proses penelitian pada konsep pengembangan ujung Suramadu yang akan dijabarkan pada tabel 1.

Tabel 1. Variable penelitian

\begin{tabular}{|c|c|c|c|c|c|}
\hline Sasaran & Variabel & $\begin{array}{c}\text { Input } \\
\text { Sub variabel }\end{array}$ & Sumber data & $\begin{array}{l}\text { Metode } \\
\text { analisis }\end{array}$ & Out put \\
\hline $\begin{array}{l}\text { Mengidentifikasi } \\
\text { kondisi } \\
\text { eksisting pada } \\
\text { kawasan ujung }\end{array}$ & $\begin{array}{l}\text { Tata guna } \\
\text { lahan sekitar } \\
\text { penelitian }\end{array}$ & $\begin{array}{l}\text { Kondisi lahan } \\
\text { pedagang } \\
\text { Kondisi lapak } \\
\text { pedagang }\end{array}$ & $\begin{array}{l}\text { Observasi } \\
\text { lapangan } \\
\text { awancara } \\
\text { Kuisioner }\end{array}$ & $\begin{array}{l}\text { Analisis } \\
\text { deskriptif } \\
\text { kualitatif } \\
\text { dan analisis }\end{array}$ & $\begin{array}{l}\text { Konsep } \\
\text { pengemba } \\
\text { ng an } \\
\text { ujung } \\
\text { Suramadu }\end{array}$ \\
\hline $\begin{array}{l}\text { Suramadu } \\
\text { Mengidentifikasi } \\
\text { fasilitas sarana } \\
\text { dan prasarana } \\
\text { yang perlu } \\
\text { disediakan }\end{array}$ & $\begin{array}{l}\text { Kondisi } \\
\text { sarana dan } \\
\text { prasarana }\end{array}$ & $\begin{array}{l}\text { Fasilitas } \\
\text { umum } \\
\text { Tempat } \\
\text { Peristirahatan } \\
\text { Tempat atraksi } \\
\text { seni budaya }\end{array}$ & $\begin{array}{l}\text { Observasi } \\
\text { lapangan } \\
\text { Wawancara }\end{array}$ & $\begin{array}{l}\text { SWOT guna } \\
\text { menentukan } \\
\text { strategi } \\
\text { pengembang } \\
\text { an Ujung } \\
\text { Suramadu }\end{array}$ & Suramadu \\
\hline $\begin{array}{l}\text { Mengidentifikasi } \\
\text { atraksi seni } \\
\text { budaya yang } \\
\text { bisa } \\
\text { menjadikan } \\
\text { daya }\end{array}$ & $\begin{array}{l}\text { Karakteristik } \\
\text { seni budaya } \\
\text { pada } \\
\text { Masyarakat }\end{array}$ & $\begin{array}{l}\text { Sosial budaya } \\
\text { khas Madura } \\
\text { (tarian, musik, } \\
\text { dan lain-lain ) }\end{array}$ & $\begin{array}{l}\text { Jurnal buku } \\
\text { dan terbitan } \\
\text { oleh media } \\
\text { masa }\end{array}$ & & \\
\hline
\end{tabular}


Buyung Adinda Lokananta \& Anak Agung Sagung Alit Widyastuty : Pengembangan Ujung Jembatan Suramadu Berdasarkan Persepsi Pedagang (Studi Kasus Desa Sukolilo Kecamatan Labang Bangkalan Madura)

\begin{tabular}{llll}
\hline Merumuskan & Faktor-faktor & Pengembangan & Analisis \\
konsep & pengembang & yang sesuai & sebelumnya \\
engembangan & an & dengan potensi & \\
ujung & sesuai & studi & \\
Suramadu & dengan & & \\
& potensi dan & & \\
& permasalahan & \\
& yang ada di & \\
& wilayah & \\
& penelitian & \\
\hline
\end{tabular}

\section{HASIL PENELITIAN}

Hasil analisis dari penelitian ini adalah :

1. Tata guna Lahan

Pada kawasan ujung Suramadu terdapat lahan kosong yang luasnya kurang lebih $4,5 \mathrm{Ha}$. Lahan ini tidak dipergunakan sebagai lahan pertanian maupun yang lain sehingga lahan yang kosong tersebut diperuntukkan sebagai area pengembangan ujung Suramadu. Luas lahan yang saat ini menjadi pusat penelitian kurang lebih $320 \mathrm{~m}^{2}$ yang dibagi menjadi beberapa bagian guna memberikan kenyamanan kepada para wisatawan. Berikut adalah prosentase dari luas lahan yang diperuntukkan sebagai area pengembangan ujung Suramadu : Lahan dan lapak pedagang yang menggunakan $37 \%$ dari luas lahan yang ada, Sarana Prasarana yang menggunakan $43 \%$ dari luas lahan yang ada dan dibagi untuk beberapa sarana prasarana yang sudah ditentukan untuk MCK, Lahan Parkir, Musollah, Tempat peristirahatan / Gazebo, Sarana informasi wisata, Pendopo (Tempat Pagelaran Seni Budaya)

2. Sarana dan prasarana

a) Hasil analisis kondisi fasilitas umum MCK sebagian besar $(97 \%$ responden) mengatakan tidak baik bahkan lebih buruk dari apa yang disediakan oleh pedagang sekitar. Adapun 3\% reponden mengatakan "sedang" karena setidaknya ada fasilitas yang disediakan namun hanya saja kurang adanya perawatan dan pemantauan yang rutin.

b) Hasil analisis kondisi fasilitas umum Musholla sebagian besar $(67 \%$ responden) mengatakan buruk karena minimnya tempat dan buruknya keadaan yang ada, adapun $30 \%$ responden mengatakan baik karena fasilitas ini letaknya lebih strategis dibandingkan dengan yang disediakan oleh pedagang. Keadaan yang dikatakan sedang oleh $3 \%$ reponden menganggap musollah yang ada kurang dari kata standar untuk kawasan wisata.

c) Hasil analisis kondisi fasilitas umum tempat peristirahatan/gazebo sebagian besar (93\% responden) mengatakan buruk karena akses menuju fasilitas ini sangat tidak strategis sehingga wisatawan enggan untuk singgah, namun $7 \%$ responden mengatakan kondisi fasilitas ini lumayan baik karena tidak adanya tempat peristirahatn lain yang ada dikawasan ini..

d) Hasil analisis kondisi sarana informasi wisata lebih banyak (58\% responden) yang mengatakan tidak berfungsinya karena akses jalan yang tidak memenuhi standar sehingga wisatawan lebih memilih untuk bertanya pada para pedagang, namun $42 \%$ reponden mengatakan fasilitas ini berfungsi sebagaimana kegunaan yang sudah diberikan oleh pemerintah karena pada sarana ini juga menampilkan letak-letak kawasan wisata lain yang ada di Madura.

e) Hasil analisis kondisi lapak pedagang yang ada di desa Sukolilo lebih banyak (73\% responden) menggunakan lapak yang berbentuk semi permanen, adapun $24 \%$ responden menggunakan gerobak dan $3 \%$ responden sebagai pedagang asongan

f) Hasil analisis lahan parkir yang ada pada kawasan ujung Suramadu terlihat jelas tidak adanya lahan khusus yang diperuntukkan sebagai lahan parkir sehingga wisatawan menempatkan kendaraannya tepat berada didepan lapak pedagang. 

Suramadu Berdasarkan Persepsi Pedagang (Studi Kasus Desa Sukolilo Kecamatan Labang Bangkalan Madura)

3. Karakteristik Sosial Budaya

a) Hasil analisis jumlah pedagang pada tiap tahunnya selalu menurun terlihat dari jumlah pedagang pada awal peresmian jembatan Suramadu tahun 2009 mencapai 120 pedagang namun pada tahun 2012 menurun menjadi 78 pedagang ini dikarenakan pedagang gulung tikar dan kembali pada profesi lama.

b) Hasil analisis tingkat pendidikan pedagang sebagian besar $(83 \%$ pedagang) mengenyam pendidikan hanya sampai SD Bahkan ada juga yang tidak bersekolah hal ini dikarenakan wilayah ini jauh dari jangkauan pemerintah serta alat transportasi, namun $17 \%$ pedagang yang ada di desa sukolilo ini mempunyai tingkat pendidikan yang setara karena memang mereka melakukan perantauan untuk bersekolah.

c) Hasil analisis karakteristik pedagang berdasarkan umur sebagian besar (96\% reponden) memang berusia produktif, namun $4 \%$ reponden yang ada berusia non produktif. d) Hasil analisis pendapatan pedagang per-bulan sebagian besar $(58 \%$ reponden)mengatakan tidak tentu karena kunjungan wisatawan tidak bisa ditentukan, adapun dibulanbulan tertentu mereka mendapatkan pendapatan lebih dari bulan biasa.

e) Hasil analisis seni budaya yang akan ditampilkan pada pertunjukan sebagian besar pedagang mengatakan seni tari dan dan seni musik lebih banyak menarik wisatawan karena tari menampilkan banyak warna dan juga mempunyai cerita yang indah sedangkan seni musik dapat memberikan kenyamanan pengunjung untuk mendengarkan lantunan musik yang sedang dimainkan.

4. Analisis SWOT

Dari gambar di atas terlihat bahwa pedagang mendapati sebuah kenyataan yang dapat suatu kawasan yang berkembang karena di mana nilai dari kekuatan dan ancaman sama. Gambara di atas dapat dijabarkan dengan strategi sebagai

berikut:

Tabel 2 Matrik Analisis SWOT

\begin{tabular}{|c|c|c|}
\hline $\begin{array}{l}\text { IFAS } \\
\text { EFES }\end{array}$ & KEKUATAN (S) & KELEMAHAN (W) \\
\hline $\begin{array}{l}\text { Peluang } \\
\text { (0) }\end{array}$ & $\begin{array}{l}\text { Strategi SO } \\
\text { Menarik wisatawan dengan menunjukan } \\
\text { dan memperkenalkan budaya dan } \\
\text { keindahan alam yang menjadi potensinya } \\
\text { Pengelola lahan yang baik dengan } \\
\text { menggandengkan investor yang } \\
\text { bertujuan untuk pengembangan yang } \\
\text { tidak mengambil keuntungan sendiri } \\
>\quad \text { Penyuluhan yang berkelanjutan untuk } \\
\text { memberikan motivasi guna } \\
\text { pengembangan kawasan }\end{array}$ & $\begin{array}{l}\text { Strategi WO } \\
>\quad \text { Penyuluhan dan pembekalan yang } \\
\text { lebih untuk mereka yang } \\
\text { berpendidikan kurang } \\
>\quad \text { Kerja sama dengan investor dalam } \\
\text { sebuah pembangunan saran } \\
\text { prasarana yang memadai } \\
>\quad \begin{array}{l}\text { Kebijakan yang terbuka dan tetap } \\
\text { membuat penduduk sejahtera }\end{array}\end{array}$ \\
\hline $\begin{array}{l}\text { Ancaman } \\
\text { (T) }\end{array}$ & $\begin{array}{l}\text { Srategi ST } \\
\text { Menjaga dan melestarikan apa yang ada } \\
\text { disekitar guna kelangsungan } \\
\text { kesejahteraan bersama } \\
>\quad \begin{array}{l}\text { Menambahkan potensi untuk menarik } \\
\text { wisatawan }\end{array} \\
>\quad \begin{array}{l}\text { Pengunaan lahan yang sesuai dengan } \\
\text { keperluan }\end{array} \\
>\begin{array}{l}\text { Keikutsertaan pemerintah untuk } \\
\text { mengenal budaya sebagai daya tarik } \\
\text { wisatawan }\end{array}\end{array}$ & $\begin{array}{ll}\text { Strategi WT } \\
\quad \text { Membentengi diri dengan keramah } \\
\text { tamahan bersikap dan teratur } \\
>\quad \text { Membuat atau melengkapi } \\
\text { kebutuhan yang seharusnya } \\
\text { dilengkapi oleh pemerintah } \\
>\quad \text { Tetap mempertahankan pemasukan } \\
\text { yang lama guna kelangsungan } \\
\text { hidup dan pengembangan kawasan }\end{array}$ \\
\hline
\end{tabular}


Buyung Adinda Lokananta \& Anak Agung Sagung Alit Widyastuty : Pengembangan Ujung Jembatan Suramadu Berdasarkan Persepsi Pedagang (Studi Kasus Desa Sukolilo Kecamatan Labang Bangkalan Madura)

\section{PEMBAHASAN}

Pembahasan dari hasil analisis penelitian adalah sebagai berikut :

1. Tata Guna Lahan Konsep pengembangan area Ujung Suramadu ini adalah menggunakan lahan yang sudah ada untuk dijadikan rest area yang menarik dan juga memberikan kenyamanan bagi pedagang untuk menggelar dagangannya. Konsep pertama yakni pembenahan aksesbilitas menuju rest area dengan menyediakan jalur paving bagi pengguna kendaraan bermotor serta tambahan rumput hijau untuk menambah kesan indah dan nyaman pada area. Dilanjutkan pada penataan beberapa fasilitas yang menjadi pendukung pada kawasan

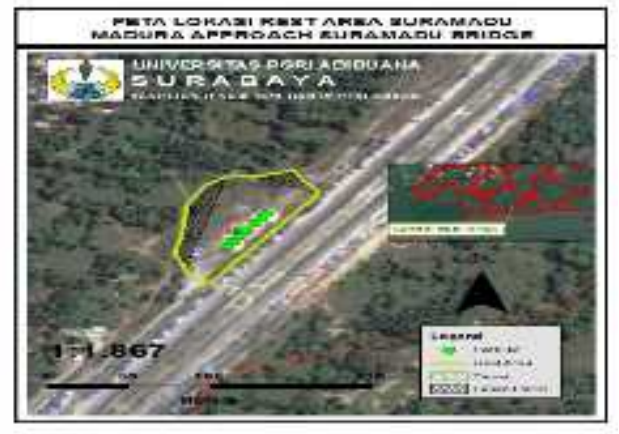

2. Sarana dan Prasarana

Sarana prasarana adalah suatu objek yang penting pada sebuah kawasan yang bertujuan memberikan kenyamanan bagi para pengunjung maupun penduduk sekitar. Pada area ujung Suramadu perlu adanya penataan bahkan perbaharuan pada bentuk sarana prasrananya, berikut adalah konsep yang ditujukan pada area ujung Suramadu:

\section{a. Fasilitas Umum (MCK)}

Letak fasilitas ini ditempatkan pada ujung area yang bertujuan untuk meminimalisir keadaan terlihat kumuh karena adanya fasilitas ini. dengan diupayakan untuk bentuk dari MCK ini tidak terlalu buruk yang menggunakan perbedaan ruang bagi pengguna wanita dan pria.

\section{b. Failitas Umum (Musholla)}

Musholla adalah salah satu fasilitas yang menjadi kebutuhan para pedagang maupun pengunjung, untuk itu perlu adanya fasilitas yang memadai serta nyaman untuk melakukan

kegiatannya. Bangunan permanen akan dapat memberikan kenyamanan serta keindahan untuk fasilitas ini.

c. Fasilias Umum Tempat Peristirahatan (Gazebo)

Tempat peristirahatan/Gazebo merupakan fasilitas yang menunjang untuk dijadikan tempat pesinggahan oleh para pengunjung dan tempat peristirahatan bagi masyarakat sekitar, untuk itu pentingnya kenyamanan serta keindahan harus menjadi keutamaan pada fasilitas ini. Letak tepat ditengah area fasilitas ini menjadi lebih mudah dijangkau.

\section{d. Lahan Parkir}

Saat ini pada area ujung Suramadu tidak tersedia lahan parkir untuk pengunjung, sehingga konsep ini memberikan arahan untuk penyediaan area parkir yang tepat berada disebelah Utara Kawasan. Letak dari area ini tepat pada pintu akses masuk dikawasan sehingga pengunjung tidak perlu berlama-lama untuk mencari area guna menempatkan kendaraannya.

\section{e. Bentuk Lapak Pedagang}

Bentuk lapak semi permanen pada area membuat kawasan ini terlihat tidak menarik, kumuh dan tidak terawat sehingga perlu adanya perubahan dan penataan terhadap bentuk lapak yang bertujuan untuk memberikan kenyamanan bagi para pedagang serta pengunjung yang akan melakukan transaksinya. Konsep ini memberikan gambaran untuk bangunan permanen yang mengikuti bentuk area sehingga membuat area perdagangan jelas terlihat dari arah manapun.

\section{f. Pendopo (Tempat Pagelaran Seni \\ Budaya)}

Pada area yang akan dijadikan pengembangan saat ini tidak mempunyai fasilitas pendopo/tempat pagelaran seni budaya hal ini juga yang membuat para wisatawan dan juga masyarakat sekitar merasa jenuh dan menganggap area ini tidak mempunyai nilai arti lebih sehingga konsep pengembangan ini memberikan tempat untuk fasilitas 
Buyung Adinda Lokananta \& Anak Agung Sagung Alit Widyastuty : Pengembangan Ujung Jembatan Suramadu Berdasarkan Persepsi Pedagang (Studi Kasus Desa Sukolilo Kecamatan Labang Bangkalan Madura)

pendopo untuk mempertunjukkan seni budaya yang dimiliki oleh Madura sehingga dengan adanya fasilitas ini akan membuat wisatawan maupun masyarakat sekitar lebih terhibur dan juga bisa mengenal seni budaya yang dimiliki oleh Madura. Letak dari fasilitas ini tepat berada disebelah Selatan dari kawasan yang dijadikan area kunjungan wisata

Tabel 3 pembahasan penelitian

\begin{tabular}{|c|c|c|}
\hline No & Variabel & Pembahasan \\
\hline 1 & $\begin{array}{ll}\text { Tata } & \text { guna } \\
\text { lahan } & \end{array}$ & $\begin{array}{l}\text { a. Tersedianya lahan yang telah diberikan oleh pemerintah untuk rest } \\
\text { area } \\
\text { b. Tidak adanya perawatan dan pantauan pada area baik sarana } \\
\text { prasarana maupun akses jalan pada area } \\
\text { c. Letak dan bentuk lapak yang buruk }\end{array}$ \\
\hline 2. & $\begin{array}{l}\text { Sarana } \\
\text { Prasarana }\end{array}$ & $\begin{array}{l}\text { Fasilitas sarana prasrana yang ada pada area ujung Suramadu tidak } \\
\text { banyak digunakan oleh para pengunjung maupun masyarakat sekitar } \\
\text { sebab sarana prasarana dari } \\
\text { a. Fasilitas MCK : Tidak terawat, persediaan air yang minim dan pintu } \\
\text { yang selalu tertutup } \\
\text { b. Fasilitas Musholla : Bentuk bangunan yang seadanya (hanya ditutup } \\
\text { dengan kayu pada sekeliling tiang bangunan) membuat fasilitas ini } \\
\text { tidak nyaman untuk digunakan. } \\
\text { c. Sarana Informasi Wisata: Tidak menarik dan juga akses untuk menuju } \\
\text { area ini tidak bagus sehingga para pengunjung enggan untuk } \\
\text { mengunjunginya. } \\
\text { d. Gazebo: Tidak adanya perawatan yang rutin sehingga tempat ini } \\
\text { terlihat kumuh dan tidak terpakai }\end{array}$ \\
\hline 3 & $\begin{array}{l}\text { Karak } \\
\text { Sosia }\end{array}$ & $\begin{array}{l}\text { Pada hasil analisa ini sebagian besar mengatakan bahwa pertunjukan } \\
\text { seni budaya yang dimiliki oleh Madura akan membuat kunjungan } \\
\text { wisatawan bertambah dan juga dapat memperkenalkan seni budaya yang } \\
\text { ada di Madura. Seni budaya yang lebih banyak diminati untuk ditampilkan } \\
\text { adalah seni tari dan seni musik karena dengan adanya pertunjukan tari } \\
\text { dan musik akan memberikan warna pada area }\end{array}$ \\
\hline 4. & $\begin{array}{l}\text { Konsep } \\
\text { Pengembanga } \\
\mathrm{n}\end{array}$ & $\begin{array}{l}\text { Penataan dengan mengkonsep area guna dijadikan sebagai area } \\
\text { kunjungan wisata yang baru yang nyaman serta melestarikan budaya dari } \\
\text { pertunjukan yang digelar. Dan juga memberikan kesempatan untuk } \\
\text { masayarakat sekitar untuk mendapatkan penghasilan tambahan dengan } \\
\text { berdagang pada area yang disediakan. }\end{array}$ \\
\hline
\end{tabular}

\section{KESIMPULAN DAN SARAN}

Jembatan Suramadu merupakan salah satu akses jalur jalan yang dimiliki oleh Pulau Madura untuk berhubungan langsung dengan wilayah lain. Dengan adanya akses Jembatan Suramadu yang diresmikan pada Tahun 2009 oleh Bapak Presiden Susilo Bambang Yodhoyono, Pulau Madura lebih banyak dikenal oleh kalangan luas serta akses Jembatan Suramadu telah memberikan kemudahan akses untuk berinteraksi dengan wilayah lain sehingga dengan kemudahan yang didapat dari akses ini menjadikan Pulau Madura lebih berkembang dari sebelumnya. Jembatan Suramadu terletak di ujung Utara Kabupaten Bangkalan yang lebih tepatnya berada di Desa Sukolilo Kecamatan Labang. Kawasan ini dulunya merupakan kawasan yang sangat terpencil dikarenakan akses untuk menuju wilayah lain sangat terbatas sehingga penduduk di Desa ini menjadi tertinggal dibandingkan dengan kawasan lainnya.

Dengan adanya pembangunan Jembatan Suramadu Desa ini mengalami banyak kemajuan dalam faktor perekonomian karena Desa ini dijadikan persinggahan oleh para pengunjung saat melakukan kunjungan wisatanya. Karena dengan adanya kunjungan wisatawan yang ada dikawasan ini maka penduduk sekitar kawasan memanfaatkannya dengan cara berjualan diarea ujung Suramadu dengan begitu penduduk sekitar mendapatkan penghasilan tambahan. Namun sayangnya dimasa 4 Tahun adanya kawasan Ujung Suramadu 
Buyung Adinda Lokananta \& Anak Agung Sagung Alit Widyastuty : Pengembangan Ujung Jembatan Suramadu Berdasarkan Persepsi Pedagang (Studi Kasus Desa Sukolilo Kecamatan Labang Bangkalan Madura)

tidak menampakkan hasil perkembangan yang bagus dimana jumlah pedagang yang ada tiap tahun semakin menurun karena kurangnya daya tarik wisatawan untuk berkunjung lebih lama pada kawasan ini.

Yang menjadi masalah penurunan jumlah pedagang serta berkurangnya daya tarik wisatawan adalah :

1.Keadaan lahan dan lapak : Lahan yang diperuntukan sebagai area pengembangan masih terlihat kosong tidak terurus, akses menuju area ini juga tidak dibenahi dengan baik sehingga area tersebut seperti area yang tidak memiliki fungsi jelas ditambah dengan adanya bekas-bekas lapak pedagang yang tidak terpakai. Lapak yang tidak terpakai itu merupakan lapak bantuan pemerintah namun pedagang tidak memakai lapak bantuan tersebut dengan alasan lapak yang diberikan tidak sesuai harapan serta ketentuan retribusi yang harus dibayar cukup tinggi maka dari itu pedagang enggan untuk memakainya.

2.Sarana Prasarana : Layak pakai dan perawatan rutin pada sarana prasarana kawasan wisata hendaknya menjadi acuan pemerintah guna pengembangan wilayah namun tidak dengan kawasan ujung Suramadu ini, Sarana prasarana yang ada dikawasan ujung Suramadu dinilai buruk dan tidak dapat digunakan selayaknya. Dengan tidak terawatnya sarana prasarana yang ada maka dapat membuat wisatawan merasa tidak nyaman untuk melakukan kunjungannya dilain waktu.

3.Potensi Seni Budaya : Keanekaragaman seni budaya serta kaya akan hal unik salah satu nilai yang baik untuk menjadikan Pulau Madura sebagai wilayah yang banyak dikunjungi. Dengan pertunjukan seni budaya adalah salah satu cara untuk menarik wisatawan merasa senang dan betah saat berkunjung dikawasan ini.

4.Arahan Konsep Pengembangan (Stability) : Penataan kawasan yang memang sudah ditentukan harus digunakan dengan baik terlebih juga menjaganya guna kelangsungan sebuah konsep pengembangan yang sedang berjalan. Campur tangan pemerintah lebih diperlukan untuk mepertahankan keadaan yang sudah berjalan seiring dengan adanya konsep pengembangan ujung Suramadu.

\section{SARAN}

1. Meningkatkan tingkat pendidikan pada masyarakat sekitar guna menambah wawasan untuk mengolah kawasan yang dapat dijadikan kawasan wisata yang baru yang dapat memberikan dampak positif pada perkembangan daerah ini.

2. Pentingnya kerjasama antara investor dan pemerintah Bangkalan guna mengembangkan kawasan untuk menjadi lebih baik, terlebih untuk pemantauan area yang sudah menjadi kawasan wisata yang baru.

3. pentingnya kebijakan dari pemerintah Bangkalan untuk menetapkan kawasan ini menjadi kawasan wisata dan memberikan arahan maupun penyuluhan untuk pengelolaan yang berkelanjutan dengan tetap menjaga serta melestarikan kawasan.

\section{DAFTAR PUSTAKA}

Anonim, Workshop Regional \& Urban Planning, Yogyakarta 13-14 Oktober 2006

Anonim, http://one.indoskripsi.com/pengembangan-wilayah-dan-penataan-ruang-di-indonesia

Anonim, http://id.Wikipedia.org/wiki/Pulau Madura

Dr. Elly M. Setiadi, M.Si.dkk, IImu Sosial dan Budaya Dasar, Prenada Media Group 2005

Garbiel Amin Silalahi, BA., MBA., MDS, Metodologi Penenlitian dan Studi Kasus, Citra Media 2003 